\title{
Editorial
}

\section{Refinement in Evidence Synthesis of Percutaneous Adhesiolysis}

Standiford Helm II, MD', Ramsin M. Benyamin, MD², and Frank J.E. Falco, MD³

T

he Institute of Medicine report on relieving pain in America $(1,2)$ showed the magnitude of pain in the United States and pain's astounding financial costs, which range from $\$ 560$ billion to $\$ 630$ billion per year. Martin et al (3) estimated that treatment for back and neck pain problems accounted for $\$ 86$ billion in health care expenditures in the United States in 2005, with a 65\% increase in expenditures and a 49\% increase in the number of patients seeking spine-related care from 1997 through 2006 . However, exploding health care costs in managing chronic pain are not an isolated issue for the United States; rather it is a global issue. Almost all countries continue to face escalating health care costs. Among various reasons for exploding costs in managing spinal pain, interventional techniques have been implicated (4). In fact, the growth of interventional techniques for managing spinal pain continues to surprise, especially policy-makers. The increasing utilization of interventional techniques is often considered to be inappropriate and occasionally unsafe, resulting in inappropriate care (4-12). Ironically, the criticism continues despite significant advances with multiple randomized, controlled trials, systematic reviews, and evidence-based guidelines (4,13-83). Even then, the available evidence documents a wide degree of variation in the definition of the practice of medicine in general and interventional pain management in particular. Manchikanti et al (5), in an assessment of all interventional techniques, except for implantables, continuous epidurals, intraarticular injections, trigger point and ligament injections, peripheral nerve blocks, and vertebroplasty procedures, showed an increase of $177 \%$ per 100,000 Medicare beneficiaries from 2000 to 2011 with an annual average increase of $11.4 \%$. This assessment showed the increases were significantly higher for facet joint interventions and sacroiliac joint blocks with an increase of $310 \%$ per 100,000 Medicare beneficiaries, whereas the increases for epidural and adhesiolysis procedures was $127 \%$. The geometric average of annual increase was also higher for facet joint interventions with $13.7 \%$ and $7.7 \%$ for epidural and adhesiolysis procedures. Of these, percutaneous adhesiolysis procedures constitute $1 \%$ of epidural injections and less than $0.5 \%$ of all interventional procedures (5-7).

American Society of Interventional Pain Physicians guidelines have demonstrated the evidence available for interventional techniques is fair or above for only $47 \%$ of the therapeutic interventions assessed (4). These guidelines illustrate a rigorousness of assessment and the paucity of literature for interventional techniques. Even then, all interventional techniques have been questioned for their efficacy and cost effectiveness. This issue of Pain Physician dispels some of the myths and demonstrates the effectiveness of placebo controlled percutaneous adhesiolysis in managing chronic radiculitis (83) and cost utility analysis of caudal epidural injections in managing chronic low back and lower extremity pain due to various pathologies (84). However, these are not the first studies to specifically show the effectiveness of spinal interventional techniques (4), including percutaneous adhesiolysis, and related cost utility analysis. In fact, Helm et al (56), in a systematic review of percutaneous adhesiolysis, and Manchikanti et al (4) in

From: ${ }^{1}$ The Helm Center for Pain Management, Laguna Hills, CA; ${ }^{2}$ Millennium Pain Center, Bloomington, IL, and University of Illinois, Urbana-Champaign, IL; ${ }^{3}$ Mid Atlantic Spine \& Pain Physicians, Newark, DE and Temple University Hospital, Philadelphia, PA.

Dr. Helm is Medical Director, The Helm Center for Pain Management, Laguna Hills, CA. Dr. Benyamin is Medical Director, Millennium Pain Center, Bloomington, IL and Clinical Assistant Professor of Surgery, College of Medicine, University of Illinois, Urbana-Champaign, IL. Dr. Falco is Medical Director of Mid Atlantic Spine \& Pain Physicians, Newark, DE; Director, Pain Medicine Fellowship Program, Temple University Hospital, Philadelphia, PA; and Associate Professor, Department of PM\&R, Temple University Medical School, Philadelphia, PA.

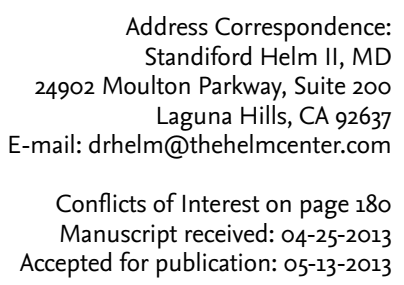


a comprehensive review of evidence for percutaneous adhesiolysis in guideline preparation, have concluded that the evidence for percutaneous adhesiolysis in post lumbar surgery syndrome and lumbar central spinal stenosis to be fair, based on a total of 6 randomized, controlled trials $(32,33,85-90)$. Even then, these studies have been chastised for not having pure placebo controls, for utilizing active-control designs, for utilizing highly selective criteria in their enrollment, for the high number of withdrawals in the control group thus invalidating the entire study, and for the studies originating from the developers or those practicing interventional pain management with high levels of interest in the procedures.

Even though none of the criticism offered is valid, clinically relevant, and methodologically appropriate, Gerdesmeyer et al (83) in a placebo-controlled, randomized assessment of the efficacy of percutaneous adhesiolysis, answered the call for such a trial. Above all, Gerdesmeyer et al (83) utilized a true placebo instead of other impure placebos or fake placebos, which have been misinterpreted by methodologists without consideration for the effects of placebos when injected into active structures such as the epidural space, over nerves, intraarticular injections, or even worse, consideration of local anesthetics as placebo $(4,9,11-40,91-96)$.

The study by Gerdesmeyer et al (83) provides high quality evidence in support of percutaneous adhesiolysis. The study is multi-centered and is methodologically sound; it has sufficient size (about 45 patients in each arm compared to the minimum required of 25 patients) and has sufficiently high benchmarks for success $(50 \%$ reduction in both Oswestry Disability Index [ODI] and Visual Analog Scale [VAS] to easily meet the criteria to be considered high quality. The study is placebo controlled, with the placebo being the injection of normal saline into the soft tissue: it meets the criteria for a placebo study rather than an active control, such as happens when local anesthetic or saline is injected around a nerve root. This is only the second study of its nature in interventional pain management with appropriate placebo, with the first study having been conducted by Ghahreman et al (40).

This study by Gersmeyer et al (83) is coupled with a previous comparative effectiveness study by the same group, showing that adhesiolysis is more effective than physical therapy in treating this population group (88).

Gerdesmeyer et al's study (83) mirrored all previous studies in having a low complication rate. There was one case of catheter shearing, which could have been caused by manipulation of the RK needle without the stylet in place, so that the tip got bent and snagged the catheter. The risk of this complication is removed by the use of Coudé $₫$ needles. While there is risk with the injection of hypertonic saline, this study confirms what other studies have found, which is that experienced operators can detect when the dura is punctured, either by dye spread or response to local anesthetic injection, and not inject hypertonic saline into the subarachnoid space.

Placebo controlled studies have the ability to show the presence of an effect and to measure the absolute size of the effect. Gerdesmeyer found that the placebo effect was about 2 points on the VAS, compared to about a 4-point reduction for the treated group, with similar changes in the ODI. This finding persisted and grew over time. Placebo/nocebo research shows that the placebo effect is greater with devices (97). Gerdesmeyer et al (83) confirm that finding as the placement of a catheter around the sacral hiatus, a device, created a placebo effect whereas providing physical therapy, no device, did not. By extension, this finding confirms the belief that procedural studies which do not show a placebo effect are flawed and should be discounted. However, this study also lacks one aspect of randomized trials (i.e., no treatment group). The study also demonstrates appropriate follow-up of 12 months.

Gerdesmeyer et al (83) did something unusual. Instead of studying the patients with post lumbar surgery syndrome or central spinal stenosis in which there is fair evidence for percutaneous adhesiolysis, they have used intractable radiculopathy which failed to respond to epidural injections for the study population, drawing the study participants from their patient population. Gerdesmeyer et al (83) must be commended for this placebo control trial, which is not feasible in the United States, which clearly shows the effectiveness of interventional techniques, specifically percutaneous adhesiolysis, with an exemplary design of a placebo. Thus, it should prove to all nihilists the efficacy of percutaneous adhesiolysis.

Another interesting finding is that the study was not performed by Racz and colleagues or Manchikanti and colleagues who have been criticized for their development and interest in this procedure.

One issue with percutaneous adhesiolysis is how the procedure differs from epidural injections with a non-spring-wired catheter. We do not know with certainty which of the factors involved in adhesiolysis is necessary for its success: the spring-wired catheter; 
whether the saline is hypertonic or normal; the use of hyaluronidase; whether the procedure is done on a oneor three-day basis; or the volume injected.

Hyaluronidase does have evidence supporting its use, although that evidence did not reach statistical significance. Gerdesmeyer et al (83) correctly point out that hyaluronidase promotes increased spread by opening up tight junctions between tissue planes, not by lysing dense surgical scar. Given that the goal of the procedure is to break up adhesions so that nerves can move freely and that medications can reach the nerves, hyaluronidase should be a part of the adhesiolysis procedure.

At this point, we do not have enough evidence to recommend normal saline over hypertonic saline.

The procedure must be done with a spring-wired catheter.

Percutaneous adhesiolysis is a safe and effective procedure to treat patients with low back and/or leg pain due to disc herniations, post lumbar surgery syndrome and spinal stenosis. With Gerdesmeyer et al's study (83), the final criterion to acceptance of this procedure, the need for a large scale, high-quality, multi-center study with long-term follow-up, has been met. We now have six high quality randomized controlled trials showing its efficacy and safety. With this level of data supporting its use, percutaneous adhesiolysis should be made widely available to these patients.

Practically, most American centers cannot do a three-day procedure because of cost concerns, meaning that the one-day procedure will continue. About $95 \%$ of adhesiolysis procedures done in the United States are done on a one-day basis.

The next issue of crucial importance for interventional pain management is cost utility. Allegedly, the effectiveness of multiple interventions for managing chronic pain is questionable. A cost utility analysis continues to be a cornerstone of evidence-based medicine, clinical practice, and health care policy making. Consequently, multiple cost effectiveness analyses/studies have been performed related to managing spinal pain (98-109). The cost effectiveness analysis in numerous studies has shown highly variable results, with cost effectiveness ranging from $\$ 304$ to $\$ 579,527$, with a median of $\$ 13,015$ for quality of life year (QALY) gain. Specifically, for the recently performed SPORT study of surgical interventions $(107,108)$, the costs for QALY gained from surgery relative to nonoperative care in lumbar disc herniation was either $\$ 69,403$ or $\$ 34,355$ based on the insurer; for spinal stenosis, the cost was $\$ 77,600$ per QALY gained, whereas for degenerative spondylolisthesis surgery, the QALY was $\$ 115,600$. The reviews of epidural injections have been highly variable, with some illustrating ineffectiveness for epidural injections. However, Manchikanti et al (84), in an analysis of 4 pathologies, with chronic low back and lower extremity pain with a 2 year follow-up for caudal epidural injections with or without steroids, using actual reimbursement data, showed a cost utility for one year of QALY of $\$ 2,206$ for disc herniation, $\$ 2,136$ for axial or discogenic pain without disc herniation, $\$ 2,155$ for central spinal stenosis, and $\$ 2,191$ for post surgery syndrome. The average cost utility analysis per year was $\$ 2,172.50$ for all patients and $\$ 1,966.03$ for patients who were judged to be successful with at least 3 weeks of improvement noted with the first 2 epidural injections.

More importantly, in this cost utility assessment, the authors have not utilized the benefits of return to employment. When return to employment was considered among these chronic patients, only a small proportion of them were eligible for employment. This evaluation shows that at the baseline, 82 out of 124 patients were employed, whereas at the end of the study, 117 out of 124 were employed, increasing employment from $66.1 \%$ to $94.3 \%$. Thus, calculating the number of individuals employed with an average salary of $\$ 34,000$ in McCracken County or $\$ 40,000$ in Kentucky, the salary benefits alone in these patients would exceed $\$ 1$ million equivalent, or higher than the total expenditures for all the procedures in these patients. Thus, cost utility is achieved even without considering improvement in all other patients who have not returned to work.

Thus, this issue of Pain Physician inaugurates a new era in interventional pain management with an outstanding placebo controlled trial, an excellent cost utility analysis involving 4 randomized trials with a large proportion of patients derived from randomized controlled trials with a 2 year follow-up and robust outcome measures.

Regardless, this may not be the end of criticism even though multiple acquisitions of interventional techniques has been dispelled. It will be interesting to see how the criticism by methodologists, nihilists, or clinicians opposed to interventional techniques about deficiencies that are non-existent in these analysis, will have to be reinvented based on new issues. 


\section{Conflict of Interest}

Dr. Helm is a clinical investigator with Epimed and receives research support from Cephalon/Teva, AstraZeneca, and Purdue Pharma, LP. He has attended an advisory group meeting for Activas.

Dr. Benyamin is a consultant with Bioness and Nevro; serves on the advisory boards of Vertos Medical and Nuvo Pharma; teaches/lectures for Vertos Medical, Boston Scientific, Neurotherm, and Bioness; and re- ceives research/grants from Alfred Mann Foundation, Teknon Foundation, Spinal Restoration, Inc., Bioness, Boston Scientific, Vertos Medical, Medtronic, Kimberly Clarke, Epimed, BioDelivery Sciences International, Inc., Theravance, Mundipharma Research, Cephalon/Teva, AstraZeneca, and Purdue Pharma, LP.

Dr. Falco is a consultant for St. Jude Medical Inc. and Joimax Inc.

\section{References}

1. Institute of Medicine (IOM). Relieving Pain in America: A Blueprint for Transforming Prevention, Care, Education, and Research. The National Academies Press, Washington, DC, 2011.

2. Cassidy JD, Carroll LJ, Côté P. The Saskatchewan Health and Back Pain Survey. The prevalence of low back pain and related disability in Saskatchewan adults. Spine (Phila Pa 1976) 1998; 23:1860-1867.

3. Martin BI, Turner JA, Mirza SK, Lee MJ, Comstock BA, Deyo RA. Trends in health care expenditures, utilization, and health status among US adults with spine problems, 1997 -- 2006. Spine (Phila Pa 1976) 2009; 34:2077-2084.

4. Manchikanti L, Abdi S, Atluri S, Benyamin RM, Boswell MV, Buenaventura RM, Bryce DA, Burks PA, Caraway DL, Calodney AK, Cash KA, Christo PJ, Cohen SP, Colson J, Conn A, Cordner HJ, Coubarous S, Datta S, Deer TR, Diwan SA, Falco FJE, Fellows B, Geffert SC, Grider JS, Gupta S, Hameed H, Hameed M, Hansen $H$, Helm II S, Janata JW, Justiz R, Kaye AD, Lee $M$, Manchikanti KN, McManus CD, Onyewu O, Parr AT, Patel VB, Racz GB, Sehgal N, Sharma M, Simopoulos TT, Singh V, Smith HS, Snook LT, Swicegood J, Vallejo R, Ward SP, Wargo BW, Zhu J, Hirsch JA. An update of comprehensive evidence-based guidelines for interventional techniques of chronic spinal pain: Part II: Guidance and recommendations. Pain Physician 2013; 16:S49-S253.

5. Manchikanti L, Falco FJE, Singh V, Pampati V, Parr AT, Benyamin RM, Fellows $B$, Hirsch JA. Utilization of interventional techniques in managing chronic pain in the Medicare population: Analysis of growth patterns from 2000 to 2011. Pain Physician 2012; 15:E969-E982.

6. Manchikanti L, Pampati V, Falco FJE, Hirsch JA. Growth of spinal interventional pain management techniques:
Analysis of utilization trends and Medicare expenditures 2000 to 2008. Spine (Phila Pa 1976) 2013; 38:157-168.

7. Abbott ZI, Nair KV, Allen RR, Akuthota VR. Utilization characteristics of spinal interventions. Spine ] 2012; 1:35-43.

8. Manchikanti L, Pampati V, Boswell MV, Smith HS, Hirsch JA. Analysis of the growth of epidural injections and costs in the Medicare population: A comparative evaluation of 1997, 2002, and 2006 data. Pain Physician 2010; 13:199-212.

9. Chou R, Huffman L. Guideline for the Evaluation and Management of Low Back Pain: Evidence Review. American Pain Society, Glenview, IL, 2009.

10. Pinto RZ, Maher CG, Ferreira ML, Hancock M, Oliveira VC, McLachlan AJ, Koes $\mathrm{B}$, Ferreira $\mathrm{PH}$. Epidural corticosteroid injections in the management of sciatica: A systematic review and meta-analysis. Ann Intern Med 2012; 157:865-877.

11. Chou R, Atlas SJ, Loeser JD, Rosenquist RW, Stanos SP. Guideline warfare over interventional therapies for low back pain: Can we raise the level of discourse? J Pain 2011; 12:833-839.

12. Manchikanti L, Benyamin RM, Falco FJE, Caraway DL, Datta S, Hirsch JA. Guidelines warfare over interventional techniques: Is there a lack of discourse or straw man? Pain Physician 2012; 15:E1-E26.

13. Manchikanti L, Singh V, Cash KA, Pampati V, Damron KS, Boswell MV. Effect of fluoroscopically guided caudal epidural steroid or local anesthetic injections in the treatment of lumbar disc herniation and radiculitis: A randomized, controlled, double blind trial with a two-year follow-up. Pain Physician 2012; 15:273-286.

14. Manchikanti L, Singh V, Cash KA, Pampati V, Damron KS, Boswell MV. A randomized, controlled, double-blind trial of fluoroscopic caudal epidural injections in the treatment of lumbar disc herniation and radiculitis. Spine (Phila Pa 1976) 2011; 36:1897-1905.

15. Nath S, Nath CA, Pettersson K. Percutaneous lumbar zygapophysial (facet) joint neurotomy using radiofrequency current, in the management of chronic low back pain: A randomized doubleblind trial. Spine (Phila Pa 1976) 2008; 33:1291-1297.

16. van Kleef M, Barendse GAM, Kessels A, Voets HM, Weber WE, de Lange S. Randomized trial of radiofrequency lumbar facet denervation for chronic low back pain. Spine (Phila Pa 1976) 1999; 24:1937-1942.

17. Manchikanti L, Cash KA, McManus CD, Pampati V. Fluoroscopic caudal epidural injections in managing chronic axial low back pain without disc herniation, radiculitis or facet joint pain. J Pain Res 2012; 5:381-390.

18. Manchikanti L, Singh V, Cash KA, Pampati V, Datta S. Fluoroscopic caudal epidural injections in managing post lumbar surgery syndrome: Two-year results of a randomized, double-blind, active-control trial. Int J Med Sci 2012; 9:582-591.

19. Manchikanti L, Cash KA, McManus CD, Pampati V, Fellows B. Results of 2-year follow-up of a randomized, doubleblind, controlled trial of fluoroscopic caudal epidural injections in central spinal stenosis. Pain Physician 2012; 15:371-384.

20. Amr YM. Effect of addition of epidural ketamine to steroid in lumbar radiculitis: One-year follow-up. Pain Physician 2011; 14:475-481.

21. Manchikanti L, Singh V, Cash KA, Pampati $V$, Falco FJE. The role of fluoroscopic interlaminar epidural injections in managing chronic pain of lumbar disc 
herniation or radiculitis: A randomized, double-blind trial. Pain Pract 2012; Dec. 27. [Epub ahead of print].

22. Manchikanti L, Cash KA, McManus CD, Pampati V, Benyamin R. Fluoroscopic lumbar interlaminar epidural injections in managing chronic lumbar axial or discogenic pain. J Pain Res 2012; 5:301-311.

23. Manchikanti L, Cash KA, McManus CD, Damron KS, Pampati V, Falco FJE. Lumbar interlaminar epidural injections in central spinal stenosis: Preliminary results of a randomized, double-blind, active control trial. Pain Physician 2012; 15:51-63.

24. Manchikanti L, Cash KA, Pampati V, Malla Y. Fluoroscopic cervical epidural injections in chronic axial or disc-related neck pain without disc herniation, facet joint pain, or radiculitis. J Pain Res 2012; 5:227-236.

25. Manchikanti L, Cash KA, McManus CD, Pampati V, Benyamin RM. A preliminary report of a randomized double-blind, active controlled trial of fluoroscopic thoracic interlaminar epidural injections in managing chronic thoracic pain. Pain Physician 2010; 13:E357-E369.

26. Manchikanti L, Cash KA, Pampati V, Wargo BW, Malla Y. Management of chronic pain of cervical disc herniation and radiculitis with fluoroscopic cervical interlaminar epidural injections. Int J Med Sci 2012; 9:424-434.

27. Manchikanti L, Malla Y, Cash KA, McManus CD, Pampati V. Fluoroscopic epidural injections in cervical spinal stenosis: Preliminary results of a randomized, double-blind, active control trial. Pain Physician 2012; 15:E59-E70.

28. Manchikanti L, Malla Y, Cash KA, McManus CD, Pampati V. Fluoroscopic cervical interlaminar epidural injections in managing chronic pain of cervical post-surgery syndrome: Preliminary results of a randomized, double-blind active control trial. Pain Physician 2012; 15:13-26.

29. Manchikanti L, Singh V, Falco FJE, Cash KA, Fellows B. Comparative outcomes of a 2-year follow-up of cervical medial branch blocks in management of chronic neck pain: A randomized, double-blind controlled trial. Pain Physician 2010; 13:437-450.

30. Civelek E, Cansever T, Kabatas S, Kircelli A, Yilmaz C, Musluman M, Ofluoglu D, Caner $\mathrm{H}$. Comparison of effectiveness of facet joint injection and radiofrequency denervation in chronic low back pain. Turk Neurosurg 2012; 22:200-206.
31. Manchikanti L, Singh V, Falco FJE, Cash KA, Pampati V, Fellows B. The role of thoracic medial branch blocks in managing chronic mid and upper back pain: A randomized, double-blind, activecontrol trial with a 2-year follow-up. Anesthesiol Res Pract 2012; 2012:585806.

32. Manchikanti L, Cash KA, McManus CD, Pampati $V$. Assessment of effectiveness of percutaneous adhesiolysis in managing chronic low back pain secondary to lumbar central spinal canal stenosis. Int J Med Sci 2013; 10:50-59.

33. Manchikanti L, Singh V, Cash KA, Pampati V, Datta S. Assessment of effectiveness of percutaneous adhesiolysis and caudal epidural injections in managing lumbar post surgery syndrome: A 2-year follow-up of randomized, controlled trial. J Pain Res 2012; 5:597-608.

35. Manchikanti L, Cash KA, McManus CD, Pampati V, Fellows B. Fluoroscopic caudal epidural injections with or without steroids in managing pain of lumbar spinal stenosis: One year results of randomized, double-blind, active-controlled trial. J Spinal Disord Tech 2012; 25:226-234.

36. Manchikanti L, Cash KA, McManus CD, Pampati V, Smith HS. One year results of a randomized, double-blind, active controlled trial of fluoroscopic caudal epidural injections with or without steroids in managing chronic discogenic low back pain without disc herniation or radiculitis. Pain Physician 2011; 14:25-36.

37. Iversen T, Solberg TK, Romner B, Wilsgaard T, Twisk J, Anke A, Nygaard O, Hasvold T, Ingebrigtsen T. Effect of caudal epidural steroid or saline injection in chronic lumbar radiculopathy: Multicentre, blinded, randomised controlled trial. BM] 2011; 343:d5278.

38. McCahon RA, Ravenscroft A, Hodgkinson V, Evley R, Hardman J. A pilot study of the dose-response of caudal methylprednisolone with levobupivacaine in chronic lower back pain. Anaesthesia 2011; 66:595-603.

39. Murakibhavi VG, Khemka AG. Caudal epidural steroid injection: A randomized controlled trial. Evid Based Spine Care ] 2011; 2:19-26.

40. Ghahreman A, Ferch R, Bogduk N The efficacy of transforaminal injection of steroids for the treatment of lumbar radicular pain. Pain Med 2010; 11:1149-1168.

41. Manchikanti L, Singh V, Falco FJ, Cash KA, Fellows B. Cervical medial branch blocks for chronic cervical facet joint pain: A randomized double-blind, controlled trial with one-year follow-up. Spine (Phila Pa 1976) 2008; 33:1813-1820.

42. Lee $\mathrm{JH}, \mathrm{An} \mathrm{JH}$, Lee $\mathrm{SH}$. Comparison of the effectiveness of interlaminar and bilateral transforaminal epidural steroid injections in treatment of patients with lumbosacral disc herniation and spinal stenosis. Clin J Pain 2009; 25:206-210.

43. Rados I, Sakic K, Fingler M, Kapural L. Efficacy of interlaminar vs transforaminal epidural steroid injection for the treatment of chronic unilateral radicular pain: Prospective, randomized study. Pain Med 2011; 12:1316-1321.

44. Kim D, Brown J. Efficacy and safety of lumbar epidural dexamethasone versus methylprednisolone in the treatment of lumbar radiculopathy: A comparison of soluble versus particulate steroids. Clin J Pain 2011; 27:518-522.

45. Manchikanti L, Singh V, Falco FJE, Cash KA, Pampati V. Evaluation of the effectiveness of lumbar interlaminar epidural injections in managing chronic pain of lumbar disc herniation or radiculitis: $\mathrm{A}$ randomized, double-blind, controlled trial. Pain Physician 2010; 13:343-355.

46. Gerszten PC, Smuck M, Rathmell JP, Simopoulos TT, Bhagia SM, Mocek CK, Crabtree T, Bloch DA; SPINE Study Group. Plasma disc decompression compared with fluoroscopy-guided transforaminal epidural steroid injections for symptomatic contained lumbar disc herniation: A prospective, randomized, controlled trial. J Neurosurg Spine 2010; 12:357-371.

47. Park $\mathrm{CH}$, Lee SH, Kim BI. Comparison of the effectiveness of lumbar transforaminal epidural injection with particulate and nonparticulate corticosteroids in lumbar radiating pain. Pain Med 2010; 11:1654-1658.

48. Burgher $A H$, Hoelzer BC, Schroeder DR, Wilson GA, Huntoon MA. Transforaminal epidural clonidine versus corticosteroid for acute lumbosacral radiculopathy due to intervertebral disc herniation. Spine (Phila Pa 1976) 2011; 36:E293-E300.

49. Tafazal S, Ng L, Chaudhary N, Sell P. Corticosteroids in peri-radicular infiltration for radicular pain: A randomised double blind controlled trial. One year results and subgroup analysis. Eur Spine J 2009; 18:1220-1225.

50. Manchikanti L, Cash KA, McManus CD, Pampati $V$, Benyamin RM. Preliminary 
results of a randomized, double-blind, controlled trial of fluoroscopic lumbar interlaminar epidural injections in managing chronic lumbar discogenic pain without disc herniation or radiculitis. Pain Physician 2010; 13:E279-E292.

51. Park KD, Lee J, Jee H, Park Y. Kambin triangle versus the supraneural approach for the treatment of lumbar radicular pain. Am J Phys Med Rehabil 2012; 91:1039-1050.

52. Kapural L, Vrooman B, Sarwar S, Krizanac-Bengez $L$, Rauck R, Gilmore $C$, North J, Girgis G, Mekhail N. A randomized, placebo-controlled trial of transdiscal radiofrequency, biacuplasty for treatment of discogenic lower back pain. Pain Med 2013; 14:362-373.

53. Kim WM, Lee HG, Jeong CW, Kim CM, Yoon $\mathrm{MH}$. A randomized controlled trial of intra-articular prolotherapy versus steroid injection for sacroiliac joint pain. J Altern Complement Med 2010; 16:1285-1290.

54. Lee JH, Lee $\mathrm{SH}$, Song SH. Clinical effectiveness of botulinum toxin A compared to a mixture of steroid and local anesthetics as a treatment for sacroiliac joint pain. Pain Med 2010; 11:692-700.

55. Patel N, Gross A, Brown L, Gekht G. A randomized, placebo-controlled study to assess the efficacy of lateral branch neurotomy for chronic sacroiliac joint pain. Pain Med 2012; 13:383-398.

56. Helm II S, Benyamin RM, Chopra P, Deer TR, Justiz R. Percutaneous adhesiolysis in the management of chronic low back pain in post lumbar surgery syndrome and spinal stenosis: A systematic review. Pain Physician 2012; 15:E435-E462.

57. Manchikanti L, Buenaventura RM, Manchikanti KN, Ruan X, Gupta S, Smith HS, Christo PJ, Ward SP. Effectiveness of therapeutic lumbar transforaminal epidural steroid injections in managing lumbar spinal pain. Pain Physician 2012; 15:E199-E245.

58. Parr AT, Manchikanti L, Hameed $\mathrm{H}$, Conn A, Manchikanti KN, Benyamin RM, Diwan S, Singh V, Abdi S. Caudal epidural injections in the management of chronic low back pain: A systematic appraisal of the literature. Pain Physician 2012; 15:E159-E198.

59. Benyamin RM, Manchikanti L, Parr AT, Diwan SA, Singh V, Falco FJE, Datta S, Abdi S, Hirsch JA. The effectiveness of lumbar interlaminar epidural injections in managing chronic low back and lower extremity pain. Pain Physician 2012;
15:E363-E404.

6o. Diwan SA, Manchikanti L, Benyamin RM, Bryce DA, Geffert S, Hameed $H$, Sharma ML, Abdi S, Falco FJE. Effectiveness of cervical epidural injections in the management of chronic neck and upper extremity pain. Pain Physician 2012; 15:E405-E434.

61. Benyamin RM, Wang VC, Vallejo R, Singh V, Helm II S. A systematic evaluation of thoracic interlaminar epidural injections. Pain Physician 2012; 15: E497-E514.

62. Simopoulos TT, Manchikanti L, Singh V, Gupta S, Hameed H, Diwan S, Cohen SP. A systematic evaluation of prevalence and diagnostic accuracy of sacroiliac joint interventions. Pain Physician 2012; 15:E305-E344.

63. Hansen H, Manchikanti L, Simopoulous TT, Christo PJ, Gupta S, Smith HS, Hameed $\mathrm{H}$, Cohen SP. A systematic evaluation of the therapeutic effectiveness of sacroiliac joint interventions. Pain Physician 2012; 15:E247-E278.

64. Helm II S, Deer TR, Manchikanti L, Datta S, Chopra P, Singh V, Hirsch JA. Effectiveness of thermal annular procedures in treating discogenic low back pain. Pain Physician 2012; 15:E279-E304.

65. Manchikanti L, Benyamin RM, Singh $V$, Falco FJE, Hameed $\mathrm{H}$, Derby R, Wolfer LR, Helm II S, Calodney AK, Datta $S$, Snook LT, Caraway DL, Hirsch JA, Cohen SP. An update of the systematic appraisal of the accuracy of utility of lumbar discography in chronic low back pain. Pain Physician 2013; 16:SE55-SE95.

66. Singh V, Manchikanti L, Onyewu O, Benyamin RM, Datta S, Geffert S, Parr AT, Falco FJE. An update of appraisal of accuracy of thoracic discography as a diagnostic test for chronic spinal pain. Pain Physician 2012; 15:E757-E776.

67. Onyewu O, Manchikanti L, Falco FJE, Singh V, Geffert S, Helm II S, Cohen SP, Hirsch JA. An update of the appraisal of the accuracy and utility of cervical discography in chronic neck pain. Pain Physician 2012; 15:E777-E806.

68. Falco FJE, Manchikanti L, Datta S, Sehgal N, Geffert S, Onyewu O, Singh V, Bryce DA, Benyamin RM, Simopoulos TT, Vallejo R, Gupta S, Ward SP, Hirsch JA. An update of the systematic assessment of the diagnostic accuracy of lumbar facet joint nerve blocks. Pain Physician 2012; 15:E869-E907.

69. Falco FJE, Manchikanti L, Datta S, Sehgal N, Geffert S, Onyewu O, Zhu J, Coubarous S, Hameed M, Ward SP, Sharma
M, Hameed H, Singh V, Boswell MV. An update of the effectiveness of therapeutic lumbar facet joint interventions. Pain Physician 2012; 15:E909-E953.

70. Falco FJE, Datta S, Manchikanti L, Sehgal N, Geffert S, Singh V, Smith HS, Boswell MV. An updated review of diagnostic utility of cervical facet joint injections. Pain Physician 2012; 15:E807-E838.

71. Falco FJE, Manchikanti L, Datta S, Wargo BW, Geffert S, Bryce DA, Atluri S, Singh V, Benyamin RM, Sehgal N, Ward S, Helm II S, Gupta S, Boswell MV. Systematic review of therapeutic effectiveness of cervical facet joint interventions: An update. Pain Physician 2012; 15:E839-E868.

72. Atluri S, Singh V, Datta S, Geffert S, Sehgal N, Falco FJE. Diagnostic accuracy of thoracic facet joint nerve blocks: An update of the assessment of evidence. Pain Physician 2012; 15:E483-E496.

73. Manchikanti KN, Atluri S, Singh V, Geffert S, Sehgal N, Falco FJE. An update of evaluation of therapeutic thoracic facet joint interventions. Pain Physician 2012; 15:E463-E481.

74. Falco FJE, Patel VB, Hayek SM, Deer TR, Geffert S, Zhu J, Onyewu O, Coubarous S, Smith HS, Manchikanti L. Intrathecal infusion systems for long-term management of chronic non-cancer pain: An update of assessment of evidence. Pain Physician 2013; 16:SE185-SE216.

75. Helm II S, Hayek SM, Colson J, Chopra P, Deer TR, Justiz R, Hameed M, Falco FJE. Spinal endoscopic adhesiolysis in post lumbar surgery syndrome: An update of the assessment of the evidence. Pain Physician 2013; 16:SE125-SE150.

76. Singh V, Manchikanti L, Calodney AK, Staats PS, Falco FJE, Caraway DL, Hirsch JA, Cohen SP. Percutaneous lumbar laser disc decompression: An update of current evidence. Pain Physician 2013; SE229-SE26o.

77. Manchikanti L, Singh V, Calodney AK, Helm II S, Deer TR, Benyamin RM, Falco FJE, Hirsch JA. Percutaneous lumbar mechanical disc decompression utilizing Dekompressor®: An update of current evidence. Pain Physician 2013; 16:SE1-SE24.

78. Manchikanti L, Singh V, Falco, FJE, Calodney AK, Onyewu O, Helm II S, Benyamin R, Hirsch JA. An updated review of automated percutaneous mechanical lumbar discectomy for the contained herniated lumbar disc. Pain Physician 2013 16:SE151-SE184.

79. Manchikanti L, Falco FJE, Benyamin RM, 
Caraway DL, Deer TR, Singh V, Hameed $H$, Hirsch JA. An update of the systematic assessment of mechanical lumbar disc decompression with nucleoplasty. Pain Physician 2013; 16:SE25-SE54.

8o. Datta S, Manchikanti L, Falco FJE, Calodney AK, Atluri S, Benyamin RM, Buenaventura R, Cohen SP. Diagnostic utility of selective nerve root blocks in the diagnosis of lumbosacral radicular pain: Systematic review and update of current evidence. Pain Physician 2013; 16:SE97-SE124.

81. Smith HS, Colson J, Sehgal N. An update of evaluation of intravenous sedation on diagnostic spinal injection procedures. Pain Physician 2013; 16:SE217-SE228.

82. Manchikanti L, Falco FJE, Benyamin RM, Caraway DL, Helm II S, Wargo BW, Hansen H, Parr AT, Singh S, Hirsch JA. Assessment of infection control practices for interventional techniques: A best evidence synthesis of safe injection practices and use of single-dose medication vials. Pain Physician 2012; 15 :E573-E614.

83. Gerdesmeyer L, Wagenpfeil S, Birkenmaier C, Veihelmann A, Hauschild $M$, Wagner K, Al Muderis M, Gollwitzer H, Diehl P, Toepfer A. Percutaneous epidural lysis of adhesions in chronic lumbar radicular pain: A randomized double-blind placebo controlled trial. Pain Physician 2013; 16:185-196.

84. Manchikanti L, Falco FJE, Pampati V, Cash KA, Benyamin RM, Hirsch JA. Cost utility analysis of caudal epidural injections in the treatment of lumbar disc herniation, central spinal stenosis, post lumbar surgery syndrome, and axial or discogenic low back pain. Pain Physician 2013;

85. Heavner JE, Racz GB, Raj P. Percutaneous epidural neuroplasty: Prospective evaluation of $0.9 \% \mathrm{NaCl}$ versus $10 \%$ $\mathrm{NaCl}$ with or without hyaluronidase. Reg Anesth Pain Med 1999; 24:202-207.

86. Manchikanti L, Rivera JJ, Pampati V, Damron KS, McManus CD, Brandon DE, Wilson SR. One day lumbar epidural adhesiolysis and hypertonic saline neurolysis in treatment of chronic low back pain: A randomized, double-blind trial. Pain Physician 2004; 7:177-186.

87. Veihelmann A, Devens C, Trouillier H, Birkenmaier C, Gerdesmeyer L, Refior $\mathrm{HJ}$. Epidural neuroplasty versus physiotherapy to relieve pain in patients with sciatica: A prospective randomized blinded clinical trial. J Orthop Sci 2006; 11:365-369.
88. Park $\mathrm{CH}$, Lee $\mathrm{SH}$, Jung JY. Dural sac cross-sectional area does not correlate with efficacy of percutaneous adhesiolysis in single level lumbar spinal stenosis. Pain Physician 2011; 14:377-382.

89. Manchikanti L, Cash KA, McManus CD, Pampati V, Singh V, Benyamin RM. The preliminary results of a comparative effectiveness evaluation of adhesiolysis and caudal epidural injections in managing chronic low back pain secondary to spinal stenosis: A randomized, equivalence controlled trial. Pain Physician 2009; 12:E341-E354.

90. Manchikanti L, Singh V, Cash KA, Pampati $V$, Datta S. A comparative effectiveness evaluation of percutaneous adhesiolysis and epidural steroid injections in managing lumbar post surgery syndrome: A randomized, equivalence controlled trial. Pain Physician 2009; 12:E355-E368.

91. Smuck M, Levin JH. RE: Manchikanti L, Singh V, Falco FJE, Cash KA, Fellows B. Cervical medial branch blocks for chronic cervical facet joint pain: A randomized double-blind, controlled trial with one-year follow-up. Spine (Phila Pa 1976) 2008; 33:1813-20. Spine (Phila Pa 1976) 2009; 34:1116-1117.

92. Manchikanti L, Singh V, Falco FJE. In response to Smuck $M$, Levin JH. RE: Manchikanti L, Singh V, Falco FJE, Cash KA, Fellows B. Cervical medial branch blocks for chronic cervical facet joint pain: A randomized double-blind, controlled trial with one-year follow-up. Spine (Phila PA 1976) 2008; 33:1813-1820; author reply 2009; 34:1116-1117.

93. O'Neill C. Re: Manchikanti L, Singh V, Falco FJE, et al. Cervical medial branch blocks for chronic cervical facet joint pain. A randomized, double-blind, controlled trial with one-year follow-up. Spine 2008;33:1813-20. Spine (Phila Pa 1976) 2009; 34:1117-1118.

94. Manchikanti L, Singh V, Falco FJE. In response to O'Neill. RE: Manchikanti L, Singh V, Falco FJE, Cash KA, Fellows B. Cervical medial branch blocks for chronic cervical facet joint pain: A randomized double-blind, controlled trial with one-year follow-up. Spine (Phila PA 1976) 2008; 33:1813-1820; author reply 2009; 34:1119.

95. Levin JH. Prospective, double-blind, randomized placebo-controlled trials in interventional spine: What the highest quality literature tells us. Spine J 2009; 9:690-703.

96. Manchikanti L, Shah RV, Datta S, Singh
V. Critical evaluation of interventional pain management literature provides inaccurate conclusions. Spine J 2009; 9:706-708.

97. Hróbjartsson A, Gøtzsche PC. Placebo interventions for all clinical conditions. Cochrane Database Syst Rev 2010; 1:CDoo3974

98. Furlan AD, Yazdi F, Tsertsvadze A, Gross A, Van Tulder M, Santaguida L, Gagnier J, Ammendolia C, Dryden T, Doucette S, Skidmore B, Daniel R, Ostermann $\mathrm{T}$, Tsouros S. A systematic review and meta-analysis of efficacy, cost-effectiveness, and safety of selected complementary and alternative medicine for neck and low-back pain. Evid Based Complement Alternat Med 2012; 2012:953139.

99. Indrakanti SS, Weber MH, Takemoto SK, Hu SS, Polly D, Berven SH. Value-based care in the management of spinal disorders: A systematic review of cost-utility analysis. Clin Orthop Relat Res 2012; 470:1106-1023.

100. Kepler CK, Wilkinson SM, Radcliff KE, Vaccaro AR, Anderson DG, Hilibrand AS, Albert TJ, Rihn JA. Cost-utility analysis in spine care: A systematic review. Spine J 2012; 12:676-69o.

101. Dagenais S, Caro J, Haldeman S. A systematic review of low back pain cost of illness studies in the United States and internationally. Spine ] 2008; 8:8-20.

102. National Institute for Health and Clinical Excellence. Guide to the Methods of Technology Appraisal. NICE, London, 2008.

103. Taylor RS, Ryan J, O'Donnelll R, Eldabe S, Kumar K, North RB. The cost-effectiveness of spinal cord stimulation in the treatment of failed back surgery syndrome. Clin J Pain 2010; 26:463-469.

104. Guillemette S, Witzke S, Leier J, Hinnenthal J, Prager JP. Medical cost impact of intrathecal drug delivery for noncancer pain. Pain Med 2013; 14:504-515.

105. Hollingworth W, Turner JA, Welton NJ, Comstock BA, Deyo RA. Costs and costeffectiveness of spinal cord stimulation (SCS) for failed back surgery syndrome: An observational study in a workers' compensation population. Spine (Phila Pa 1976) 2011; 36:2076-2083.

106. Whynes DK, McCahon RA, Ravenscroft A, Hardman J. Cost effectiveness of epidural steroid injections to manage chronic lower back pain. BMC Anesthesiol 2012; 12:26.

107. Tosteson AN, Skinner JS, Tosteson TD, Lurie JD, Andersson GB, Berven S, Grove MR, Hanscom B, Blood EA, 
Weinstein JN. The cost effectiveness of surgical versus nonoperative treatment for lumbar disc herniation over two years: Evidence from the Spine Patient Outcomes Research Trial (SPORT). Spine (Phila Pa 1976) 2008; 33:2108-2115.

108. Tosteson AN, Lurie JD, Tosteson TD,
Skinner JS, Herkowitz $\mathrm{H}$, Albert T, Boden $\mathrm{SD}$, Bridwell K, Longley $\mathrm{M}$, Andersson GB, Blood EA, Grove MR, Weinstein JN; SPORT Investigators. Surgical treatment of spinal stenosis with and without degenerative spondylolisthesis: Cost-effectiveness after 2 years. Ann Intern Med
2008; 149:845-853.

109. Parker SL, Fulchiero EC, Davis BJ, Adogwa O, Aaronson OS, Cheng JS, Devin CJ, McGirt MJ. Cost-effectiveness of multilevel hemilaminectomy for lumbar stenosis-associated radiculopathy. Spine J 2011; 11:705-711. 